\section{THE VALUE OF AN EPISTEMOLOGICALLY- BASED CONCEPT OF CRITICAL THINKING (CT): A CRITIQUE OF A PURE CT-PEDAGOGY AND A SCIENTIFIC PARADIGM OF CT}

\section{Ma. Andrelita S.Cenzon'}

\section{Critical thinking Pedagogy without an Explicit Critical Thinking Concept}

The widespread attention given to the idea of critical thinking as something desirable to teach students in all educational levels and areas is well known. As evidenced by the proliferation of conferences and literature about critical thinking, its interest has extended beyond the educational realm to include business, information technology, the arts, etc. Most often, the advancement of teaching critical thinking in both educational and non-educational sectors is made on the account of its alleged usefulness to strategically cope with the 21st century's predicted technological, competition-driven, and multi-complex situations and problems. It is not uncommon to find justificatory statements for

\footnotetext{
${ }^{1}$ Assistant Professor, University of Asia \& the Pacific.
}

teaching thinking similar to the following: "The purpose of teaching thinking is to prepare students for a future of effective problem solving, thoughtful decision making, and life learning" (Tishman et al., 1995). We can call this the external pragmatic valuing of critical thinking-pedagogy. It is pragmatic for its utilitarian character, and it is external because its teaching is aimed to enable students to succeed.

There has been less conceptual theorizing about critical thinking than there has been about its pedagogy. Perhaps, the former may be considered unnecessary except for some philosophers of education, educational, and psychological theorists. A great number of educational practitioners may indeed happily do without theorizing just as long as they can elicit specific critical thinking-behaviors among students. This would be an instance of educational praxis valued for the result it generates without bothering about the theory that should substantiate it. It can be referred to as internal pragmatic value. It is internal because it aims at the very goal for which such critical thinking pedagogy is created and utilized. But it may also well be the case that this particular instance of educational praxis eventually leads to critical thinking theorization. The circularity of theory/praxis becomes apparent but praxis takes primacy over theory. This primacy may not assure the pursuance of a theorization of critical thinking, at least not necessarily.

In this respect, it is possible that the intellectual behavior promoted supposedly by critical thinking-pedagogy end up determining what the concept of critical thinking is. In other words, the be- 
The Value of an Epistemologically-based Concept of Critical Thinking (CT):

havior is taken to constitute the concept. This confusion is seen in some literature wherein a list of critical thinkingbehaviors is given without any attempt to explain what critical thinking is or without distinguishing the concept from its behavioral expressions. This fuzziness contributes further in not being able to clearly distinguish critical thinking from say problem-solving thinking, analytical thinking, deductive thinking, and creative thinking, etc. (if such differentiation exists). To cite an instance, the idea of proposing problembased learning as a method for developing critical (and productive) thinking to prepare medical students to become physicians states, among other things, that they need to learn the qualities of critical thinking and problem solving (Widjajakusumah et al., 1997). However, no explanation has been made regarding any of these two kinds of thinking: what they are in themselves or what sort of relationship exists between them. This fuzziness weakens any discussion about the subject because critical thinking as thinking must seek conceptual clarity and its pedagogy must be clearly taught. The latter cannot be attained without the former because, at least theoretically, the clarity of the process of teaching critical thinking depends to some extent on the clarity of what its concept is.

This paper attempts to defend the need for an epistemological concept of thinking as a result of its absence in pure critical thinking pedagogies. This need however, is not just a practical answer to a theoretical void.

Section one, Epistemology and Critical
Thinking, shows that the need for an epistemological concept of critical thinking is an intrinsic onebecause of the latter's epistemological underpinning.

Section two, Siegel's Contribution ...Implications, borrows from Harvey Siegel's concept of critical thinking to discuss the intrinsic relation of critical thinking to epistemology. Siegel's concept succeeds in clarifying what critical thinking is and in transcending the skillversus-attitude-debate about critical thinking. The concept also opens the idea of rationality as a permanent, noncultural, non-historic goal for critical thinking education. Having pointed this out, I defend the position that the reason component of critical thinking is transcultural and transhistoric, even when cultural influences may weaken the attitude component of critical thinking.

Section three, Rationality, Critical Thinking, Culture, is a discussion of rationality itself . In it, I argue that critical thinking requires some understanding of the nature of justificatory reasoning, through evidence that may be empirical or otherwise.

Section four, Critical Thinking and Science, further discusses the justificatory reasons in science. I present scientific rationality in its two models of verificationism and falsificationism. A critique is made of the limits of both models in relation to critical thinking. I argue that critical thinking is not reducible to scientific rationality because the latter cannot defend or critique itself without falling into circularity. Such defense or critique should be made by a 
critical thinking that is based on an epistemology or a broader theory of reasoning and justification.

The summary briefly concludes that pure critical thinking pedagogies without an explicit epistemological ground are ineffective and weak. It also concludes that science may be a good start for teaching critical thinking, but certainly cannot be the paradigm of critical thinking without usurping an epistemological function it was not meant to have.

\section{Epistemology and Critical Thinking}

Educationists may not problematize the theoretical substantiation of critical thinking-pedagogy praxis as it is by philosophers of education. This is not surprising since education enjoys its disciplinary autonomy and carries on without having to concern itself necessarily with the philosophical-epistemological - underpinnings of its theories and praxes (Best, 1972; Reid, 1972). While this can be agreed upon, it is also true that there are certain latent philosophical ideas that educational theories and praxes wittingly or unwittingly import. In the particular case of critical thinking, it would not be difficult to agree on the idea that the intellectual phenomenon of thinking of which critical thinking is a sort (since not all thinking is critical, otherwise it would be senseless to qualify it as critical), very well falls under the scrutiny of philosophical more specifically epistemological- inquiry.

One important contribution of contem- porary philosophy of education in the critical thinking discussion is the provision of a conception of critical thinking itself. While education should concern itself rightfully about how critical thinking is best taught, it belongs to epistemology to inquire about what critical thinking is, even when others (educationists, psychologists) try to contribute as well in this regard (Tishman et al., 1995). ${ }^{2}$

The term critical suggests making a critique of thought processes. The term thinking as a gerund emphasizes the actual engagement in intellectual processual activities rather than the end product, which is a thought, idea, or knowledge. Examining assumptions, checking for ambiguities in ideas and their expression, clarifying meanings, assessing and doing a critique of thinking itself are activities of critical analysis, which in turn, is inherent to philosophy, and in particular, to epistemology. Epistemology, that is, the branch of philosophy that studies theory of knowledge concerns itself with issues about what knowledge is, how we know that we know, on what grounds we say that some claim is such. Though philosophical queries usually articulate these concerns with words like knowledge, knowing, or to know, it would make epistemology no less relevant to the analysis and valuing of thinking and critical thinking because thinking and knowing refer to essentially the same intellec

\footnotetext{
${ }^{2}$ This work is practical in its approach but provides interesting bibliography for the theory part of thinking for each chapter that comes mainly from psychological and educational research.
} 
tual process. Epistemology studies the nature of support that is given to some knowledge-claim statements. It has to do with the very concept of critical thinking as reason seeking that should be based on criteria. Therefore, epistemology is directly relevant to critical thinking pedagogy since the latter aims to teach students to seek reasons for the knowledge-claim statements they are offered in and outside the schools and universities. In other words, an epistemology impinges on the inquiry about critical thinking by necessity, at least from a philosophical perspective.

When epistemology is introduced in the discussion of critical thinking, both educational practitioners and philosophers of education mutually benefit. The critical thinking-pedagogies or thinking courses can gain in "intellectual weight" (Siegel, 1997:24). Philosophy is given the chance to extend its epistemological contributions beyond its own confines, thereby making itself relevant to other areas.

\section{Siegel's Contribution to the Discussion of the Need for an Epistemologically based Concept of Critical Thinking. Some Implications}

Among the epistemic conceptions of critical thinking available (Winch, C. Gingell, J. 1999), this paper mainly borrows from Harvey Siegel. His concept tries to treat the skills and attitudes aspects of critical thinking in a way that incorporates them, transcending the educational and philosophical contemporary debate about the relevance and place of these two dimensions of critical thinking.

After reviewing alternative critical thinking conceptions from R. Ennis, R. Paul, J. McPeck (Siegel, 1988:5-31) and more recently, disclaiming critical thinking as a skills-alone view against C. Missimer (Siegel, 1997: 55-71), Siegel continues to defend his conception of critical thinking as involving both skills that enable appropriate reason assessment and attitudes that actually dispose believing, judging, and/or acting as a result of the compelling force of such assessed reasons. In short, the critical thinking attitudes move the thinker appropriately, i.e., guided by such reasons. (Siegel, 1997: 2-3). A critical thinker is one who is appropriately moved by reasons. By this is meant that two distinct but inseparable components constitutes critical thinking: reason assessment and critical spirit. These two are explicitations of what has to be understood by the terms appropriate and moved in the expression "appropriately moved by reasons."

The salient contribution of Siegel is three-fold. First, his critical thinking conception is not entirely intellectualistic because it does not exclude attitudes or character traits. In fact, the latter are specifically identified as critical thinking attitudes, i.e., they are directly relevant but not synonymous to the reason assessment skill. The distinction is clearly made on the one hand between knowledge of appropriate reason assessment criteria vis-à-vis attitudes; on the other hand, distinction is made between attitudes that enable one to actually/habitually engage in reason assessment vis-à-vis general character traits that 
have no direct bearing on reason assessment (e.g. moral traits). Second and most importantly, he has developed a strong defense of critical thinking on the basis of a fundamental but sufficiently broad epistemic notion, namely rationality. Rationality is understood as being "coextensive with the relevance of reasons" (Siegel, 1988: 33). Third, it can "either be said that through critical thinking, he establishes a stronger connection between rationality and education or that through rationality, he establishes that connection between critical thinking and education. This connection is revealed when Siegel states that "education [should be] aimed at the fostering of rationality and the development of rational persons" (Siegel, 1988: 32), In so stating, Siegel means more than just instantiating an education of reason through the promotion of critical thinking. It means nothing less than saying that critical thinking is the educational equivalent of educating rationality. The seriousness of rationality warrants its education, and therefore warrants the seriousness of educating in critical thinking.

Siegel conceives rationality as an educational ideal (expressed in his book's title "Educating Reason"). He specifically considers critical thinking as an educational cognate of rationality (Siegel, 1988: 32). He agrees with educationists who defend critical thinking as an educational ideal but not for the same reasons, i.e., not necessarily for the external and internal pragmatic values of critical thinking mentioned earlier.

By specifying critical thinking as an educational cognate of rationality,
Siegel transcends the strictly educational arena by pointing to rationality as the referent of the term critical thinking. By indicating this referent, Siegel includes but transcends the philosophical debate about the skill versus attitude components of critical thinking because he admits the reason assessment skills and having the dispositions of mind that engage one to actually evaluate reasons and be moved by them as both constitutive of critical thinking. He transcends the debate critical thinking-skill view versus critical thinking-attitude view by embracing rationality of which critical thinking is a cognate. This implies a serious epistemological commitment to provide and assess reasons that justify being rational and to actually be moved by those reasons.

In other words, the force of reasons for thinking and acting in a rational way rather than otherwise would justify rationality itself. Once a person knows the reasons that support rationality, how to assess the reasons why rationality is so claimed, and is actually moved by such reasons to think and behave rationally, then, he would be in a position to give greater intellectual weight to provide and assess reasons as to why critical thinking is claimed as an educational goal worth aiming for; moreover, he would actually be justified to be moved by such reasons to engage in it and to teach it. "If we cannot say why we should be rational, then we cannot justify educational efforts aimed at fostering critical thinking (...) Our efforts to justify our regarding critical thinking as a fundamental educational ideal hinge on our ability to answer the question, "Why be rational?" (Siegel, 1997: 87) 


\section{Rationality, Critical Thinking, Culture}

The appreciation of rationality as the referent of critical thinking-will theoretically ground pedagogies better than they currently are. It will also reflect the idea that critical thinking is a permanent educational goal and that the pedagogies that promote it are demands of education itself rather than historical trends occasioned by the late $20^{\text {th }}$ and the future $21^{\text {st }}$ centuries' challenges. It ultimately underlines the idea that critical thinking is fundamental to every human person regardless of culture because rationality defines humanness. If all this is true, then, the teaching of critical thinking indeed becomes a rational and educational ideal for everybody notwithstanding some cultural influences that can either promote or delay its development in different people. Certainly, the liberal democratic cultural environment which characterize North America and other places hasten the development of critical thinking of its people from their early years. This is a matter of advantageous fact. The absence of this western democratic environment, together with the presence of other traditions and ways of thinking that are a result of cultural and sometimes religious traditions slow down if not impede critical thinking in some Asian places.

For instance, the traditional Chinese cultural value of unquestioning respect for authority (parents, superior) does not only account for the underdevelopment of critical thinking but also of science in the past (Baoyun, 1998: 87). This Chinese way of thinking is partly due to the negative influence of Confucian thought which emphasizes moral ethics but neglects reason (Baoyun, 1998: 87).

The same cultural "un-questioning authority" value may be seen among Filipinos. On the one hand, this is partly due to the pacifist and cheerful kind of people they are; it is also greatly due to a cultural value of avoiding shaming others, losing facing, and to an extreme personalism that favors close family ties and friendship on the other (Pertierra, 1998: 132-133). All these cultural influences, at least in their more negative influences on critical thinking, together with a kind of an individually tailored mental sluggishness (despite the high rate of literacy and schooling), explain -but do not justify- why Filipinos are, dispositively speaking, unlikely to subject matters to rational assessment.

Perhaps too, one could consider the differences between western thinking and eastern (Asian) thinking tendencies, without ignoring further varieties within this overly simplified categorization. Western thinking -at least from Descartes- tends to dichotomize. Hence, the western mind readily makes distinctions between concepts, and draws divisions for example, between the rational and the ethical. Eastern Asians tend to think holistically. It is not easy to separate "ways of thinking" from "values embraced," or "cultural customs" from "religion." (Caquelin et al., 1998: 15)

Nonetheless, it is doubtless possible to teach Asians critical thinking by teaching them to assess reasons with reason. Redundant as this might appear, this is meant to emphasize that critical think- 
ing aims to discriminate as well as recognize reasons as reasons, and such recognition of reasons can teach Asians to use reasons to account for their ways of thinking, believing and acting even when they do so from their respective cultural and religious backgrounds. The reason component of critical thinking can still be drawn in any cultural context. In so far as it can be drawn, it is possible to engage in critical thinking.

It is also well known that current historical and cultural developments have heightened the need for critical thinking. Such is the phenomenon of globalization However, these situations occasion -extrinsically at that - critical thinking's relevance to education rather than cause it. It is rationality that intrinsically posits critical thinking's fundamental place in education. Education in rationality or its cognate critical thinking aims to educate what is most primordial for human living: reason. Without rationality and without reason's adequate education, people become cognitively blind and paralyzed since all conscious human choices, actions, and decisions depend on previous or concurrent relevant knowledge and the assessment of reasons supporting any knowledge claim.

Rationality is the theoretical substantiation of critical thinking pedagogies. But what is rationality? The variety of theories about rationality are theories that inquire about the nature of reasons and the nature of their justificatory power to claim or disclaim something in different ways (as truth, hypothesis, prediction, belief, etc.). Would critical thinking as an educational cognate of rationality then involve educating teachers and students about these epistemologies? Would teachers require some background in epistemology to be able to critically think and teach such thinking? A cursory review of epistemological theories shows abundant literature that would be just too much -in depth, in breadth- to learn by critical thinking teachers, most of who are teachers not philosophers. If one were to choose from these epistemologies, which one would be sufficient -at least for the purposes for which critical thinking is being discussed among educators?

Epistemologists would agree that if critical thinking were to be understood, one would need to have at least some idea about the nature of a reason and the nature of a warrant or justification. Critical thinking requires an understanding of the function of reason other than the explicative one. There are reasons whose purpose it is to explain (explanatory reasons); there are reasons whose aim is to justify (justificatory reasons). Explanatory reasons do not necessarily justify.

A critical thinker is one who is appropriately moved by reasons, but not by explanatory reasons. These may still remain as information. For instance, to be able to say that "global warming is explained by the accumulation of greenhouse gases in the atmosphere" does not by itself support or justify my claim of the statement's, say, truth, falsehood, or hypothetical character. Critical thinking involves more than explanatory reasons; it requires justificatory reasons, i.e., reasons that weigh in support of our acceptance, rejection, doubting, belief, 
or exploration of plausible alternatives to an idea, information, knowledge, or belief.

Alston (1995: 321) distinguishes between "one's being justified in believing that p" and "one's justifying one's belief that p." While Altson considers the former more fundamental to the issue of epistemic justification itself because there are cases when the latter is not needed, the latter -one's justifying one's belief that $\mathrm{p}$ - remains fundamental to critical thinking as a evaluative dynamic process. Justificatory reasons are needed by critical thinking because they are reasons that should and can answer the question: What is it that explains "one's justifying one's belief that p" when justifying "involves one's doing something to show that $p$, or to show that one's belief was justified, or to exhibit one's justification?" (Altson, 1992: 321) In other words, justifying comes close to the critical spirit component of Siegel's conception of critical thinking because it is not enough to have appropriate justificatory reasons but to be moved actually by those justificatory reasons.

Of the many traditional, contemporary, and not easily reconcilable theories of rationality, knowing, and concepts of epistemic justification available, mainstream epistemology accounts for knowledge as "justified true belief" and sometimes as "true belief that is justified by being caused by a reliable process" (Moser and vander Nat, 1995; also Pojman, 1995: 130). Traditional epistemologists and the majority of non-philosophers including critical thinking practitioners have no difficulty in accepting the notion of justification as "evidenced justification". The traditional view of epistemic justification, that is, that there exists a sufficient indication for a claim to be true is through evidence (empirical or otherwise). The evidence advanced functions as the justifying reason to accept that $p$.

In this light, a critical thinker would be one who is appropriately moved by evidence. Evidence would verify and justify or warrant that which is claimed. If evidence is unavailable, critical thinking demands a temporary suspension of assent to what is claimed. John McPeck calls this suspension reflective skepticism because it results from a judicious suspension of assent. McPeck's idea of a critical thinker is one who has both the skill and attitude to question the power of $e$ to warrant $p$. For him, a critical thinker is one who can evaluate the extent to which $e$ actually provides evidential reasons that compels him to assent to $p$. In the absence of such evidence, the critical thinker withholds his assent. This common-sense epistemic behavior is ordinarily accepted. However, Siegel argues that McPeck's skepticism defines critical thinking constitutively, and as such, cannot be acceptable. Siegel argues that critical thinking cannot be defined by judicious skepticism because if it were so defined, such disposition would have to be applied apriori to all instances of critical thinking and therefore to every instance of justification. Critical thinking as appropriately moved (evidenced) by reason may warrant instances when judicious skepticism is justified. Agreed. But, critical thinking may also warrant the application of skepticism as unjustified (Siegel 1987: 22-23). Hence, any instance of unjustified skepticism weak- 
ens a concept of critical thinking defined by skepticism.

\section{Critical thinking and Science}

A concept of critical thinking should be one that can admit verificationism or the possibility of justifying something specifically through empirical evidence as well as judicious skepticism if justified. We know that verificationism is involved in inductive thinking, which in turn consists of a way of justifying a claim through the search of evidence. In the case of the empirical sciences, inductive reasoning and empirical evidence seeking are engaged in. Their justificatory manner inherently involves assessment of reasons and evidences and therefore is relevant to critical thinking and critical thinking teaching.

There is however a limit to both a verificationist way of justifying using empirical criteria alone and to a theory of thinking that validates knowledge only by its justification from observable facts. Thinking critically about, say, the observable fact formulated by the science teacher in the statement $\mathrm{p}$ "liquid $\mathrm{X}$ boils at the $150^{\circ} \mathrm{C}$ " may imply that the teacher is justified in claiming $p$ because $\mathrm{s} / \mathrm{he}$ has evidence (e). If Siegel's conception of critical thinking in its general formulation is adequate, a teacher can be claimed to think and teach critically when s/he has supporting reasons available to him/her. This internalist justification implies that $s /$ he is justified to claim $p$ on the basis of his/her access to supporting reasons $e$, that is, on being able to cite those reasons (Moser, 1995: 334). Accessibility may be through the memory of $p$ and $e$, reflection, the abil- ity to give reasons when asked, etc. To strengthen this justification against criticisms to internalism, the teacher can adapt further a reliabilist - externalist justification by showing critically that his/her claim is accounted for by reasons that depend on reliable processes (Pojman, 1995: 129). Reliabilism implies more than having reasons; it implies whether those reasons are produced or supported by reliable criteria. ${ }^{3}$ In the case of science, this would mean scientifically reliable experimental processes and theories.

If the idea of scientific inductive rationality requires that an inference leading to a general theory that explains data be made from experimental data, then, the rationality that critical thinking would assume would be scientific rationality. This rationality involves making the inference that a hypothesis " $X$ " about phenomenon "Y" needs to be tested in a relevant variety of reliable and controlled conditions so that other possible explanatory reasons are eliminated. Thus, to critically teach and justify the claim $p$, "humans do not come from apes, but that our cells come from the bacterial world," would involve exhibiting reliable criteria and reasons to the students. But in so doing, that which is claimed and affirmed should no longer be considered a word translation of a pure observable fact. The science

\footnotetext{
${ }^{3}$ For the present discussion of critical thinking, the general meanings of internalism, externalism, or reliabilism given would suffice. For the alternative meanings of these theories within the philosophical debate, see Pojman (1995) or Moser (1995).
} 
teacher uses the words "bacteria," "world," and "cell" that in turn require an explanation for which s/he uses other scientific biological concepts and processes: DNA, RNA, energy, mutation, bacteria, temperature, oxygen, etc. These concepts are no longer themselves pure empirical observable data.

Therefore, if using the reason assessment criteria of critical thinking, one were to affirm that science teaches critical thinking, it is arguable that such a claim can be defended appropriately by simply making a general statement that "science teachers aim beyond providing scientific facts to students". Critical thinking teaching in science cannot consist in-reduced to- teaching students to explain observable data with formulated scientific theories (explanatory reasons). Critical thinking requires a deeper inquiry about how an observable fact is to be taken as evidence that supports or justifies a scientific concept that has been explained to students. Thinking critically goes as far as questioning the merits and limits of inductive thinking itself as it is utilized in scientific inquiry. In other words, critical thinking can question the merits and limits of the reliability of the justification process of science's own method.

It is well known that the inductive thinking process in science consists of several sub-processes in which critical thinking is involved. From the singular propositions derived from the observation of empirical phenomena, one proposes general proposition or hypothesis. The hypothesis in turn is verified through repeated and rigorous experimentation if it is to become a scientific law. In the past, the idea that scientific thinking expressed and modeled an idea of rationality by the double ways of "empirical justification" and "verification" was generally accepted. Critical thinking in science involves justification when scientific thinking advances positive evidence to support or prove a hypothesis and/or law. By verification, science justifies these propositions aposteriori, that is, after experimentation. If the generally accepted idea that "this particular view of scientific thinking models rationality" were true, then, science would be paradigmatic of critical thinking.

Critical thinking itself has led Karl Popper to criticize the inductiveverificationist-justificationist thinking in science. For him, contrary to logical empiricists, scientific propositions have to be falsifiable rather than verifiable (Popper, 1971:47). To give positive reasons (justification) or empirically check, the consequences that justify that a theory is true is logically impossible. If Popper is right, his critique does not only challenge science. We could use it, for the purpose of our discussion, to weaken the idea of scientific rationality if such were made to be paradigmatic of critical thinking. What is crucial in scientific thinking -and any thinking or growth in knowledge- in the Popperian view is not so much the ability to justify a belief or verify a hypothesis, as it is the ability to falsify it or conjecture about it.

Which theory of rationality would be appropriate to critical thinking if it is indeed the educational cognate of rationality? If the Popperian idea of scien- 
tific rationality is accepted, it would imply that critical thinking consists mainly in the ability to subject to critique any proposition in order to check its falsifiability before a person can take it seriously. It would appear that a Popperian derived idea of critical thinking would contrast quite sharply with Siegel's idea -ability to assess and be moved by reasons- because the former seems to be essentially falsificationist while Siegel's critical thinking appears to be basically justificationist. Siegel's justificatory view of critical thinking certainly includes the skills and attitudes to falsify, conjecture, and critique. But, unlike a Popperian derived view of critical thinking, the falsificationist skills and attitudes would not and cannot constitute critical thinking alone. Critical thinking in Siegel's sense, even in science, would not reduce the status and function of reason seeking to a pure falsificationist and criticist one.

If critical thinking were to be reduced to falsificationist thinking as a consequence of having been derived from the Popperian sense of scientific rationality, critical thinking would connote and affirm the negative and pejorative meaning generally attached to the term "critical thinking or critical thinker." Without any qualifier given to the expression critical thinking, say, "in the good sense", a critical thinker is commonly thought among the general public, especially in the Asian context, as someone who questions arbitrarily to eventually negate previously received information, belief, or tradition, or one who openly challenges truth negatively to debunk it, or one who pays no respect for the authority from which or through which such information, beliefs or tra- ditions have been received. It can be argued that a critical thinker in a Popperian-derived sense would not be interested in the search for some truthvalue about what is proposed for belief or acceptance or that a critical thinker would engage in critical thinking for its own sake. That is to say, critical thinking would be engaged in for the intellectual manipulative delight its processes produce in the thinker, without the latter getting seriously interested in any answer. If critical thinking were further reduced to this state, it would not be far from being the kind of sophistry Socrates criticized centuries earlier.

Inductive thinking and justifying through scientific verification has its merits and limits. But endorsing a complete Popperian derived sense of falsification cannot necessarily bring these to light. Critical thinking itself subjects Popper's fallibilist theory to a critique that denies it full validity even in science. It is not possible for scientific thinking or for thinking in general to be reduced to a never-ending process of falsification without either expecting some truth-value at the end of the thinking process or hoping for a certain psychological and cognitive rest in getting some answers to questions/dilemma, even when these are tentative or incomplete. Rest does not necessarily imply mindlessness or absolute skepticism. This rest takes the form of some degree of understanding of a particular issue. Critical thinking would aim for both intellectual inquiry and rest. A critical thinker would not be someone who either assesses reasons and is moved by them continuously in all instances or one who habitually misses to do so. It is also clear that a person who is mentally slug- 
gish to begin, maintain and finish inquiry cannot be a critical thinker.

Critical thinking cannot be reduced to scientific thinking in either the more traditional verificationist sense (logical empirism) or in the Popperian falsificationist sense. If the former were admitted, that is, if critical thinking were éssentially constituted and defined by science, that stance would weaken science to engage in critical thinking about itself. To argue that because critical thinking is nothing else but engaging in scientific rationality and that it justifies the arguer to claim that teaching scientific thinking is paradigmatic of critical thinking would imply a circular argument. There can be a logical form in this argumentation: a conclusion could be true if it follows a true premise. But it is also arguable that Formal Logic by itself is sufficient to justify or prove a claim. ${ }^{4}$ This makes of the philosophy course on Formal Logic and Mathematics, both characterized by deductive reasoning, weak contenders for engaging and teaching critical thinking, though not necessarily irrelevant to it.

The kind of rationality critical thinking assumes does not heavily require Formal Logic-though it does not preclude it- as it does Epistemology because the content of what is claimed and the context in which the content is claimed have a direct bearing as to whether the

\footnotetext{
${ }^{4}$ It is interesting to note that discussion about justification of claims is made mainly in epistemology, not in formal logic literature. This does not preclude the relevance of Formal Logic for critical thinking as Siegel posits in disagreement with McPeck (1988: 2426).
}

reasons accessed and reliably given are indeed appropriate and actually move one to accept or reject the claim. Sometimes, a claim is logical, i.e., formally correct but still fails in the reason assessment part and consequently, cannot move one to accept it.

A failure appears in the reason assessment part of the claim that science is paradigmatic of critical thinking. If it were true that rationality is identified with scientific rationality, that such rationality is accessible by way of empirically-based reasons, or that the scientific method (itself considered constitutive of science) is entirely objective, (that is, alien to contextualization or interpretation of any kind) then, that "science is indeed paradigmatic of critical thinking" could be true. Fortunately, the challenges made to these premises should engage one to critically think about that claim (Hermida: 2000). Critical thinking requires the assessment of those reasons that disclaim science's paradigmatic assertion of employing objective, non-contextualized, and interpretationfree thinking (Popper, 1971; Kuhn, 1970). In short, critical thinking (which is not equated with science) demands the consideration of alternative justificatory thinking other than through empirical evidence.

\section{Summary}

This paper has tried to draw attention to the conceptual need for a theoretical understanding of critical thinking as a concept, not as pedagogy. This is due to the observation that its conception has been neglected in many critical thinking 
pedagogy literature and related conferences. A serious engagement in critical thinking teaching requires of its teachers and practitioners a concept of critical thinking together with a basic understanding of some fundamental epistemology. Epistemology provides the intellectual support to a concept of critical thinking, and the latter provides the intellectual frame to its pedagogy. Understanding the epistemological base will by necessity make pedagogy assume a critical thinking concept.

Pedagogies without a critical thinking concept and without an epistemology would be weak, unconvincing, and most importantly, ineffective to teach critical thinking in a way that transcends the utilitarian value of the pedagogies. That is to say, without a concept, the critical thinking pedagogies cannot provide reasons for their promotion other than their strategic internal or external usefulness. If asked why critical thinking strategies need to be employed at all, or why critical thinking has to be taught, the answer might not likely go beyond the usual remarks: "Critical thinking teaches students to think actively, be creative, solve problems, check the assumptions of what is being told them, infer correctly, etc." Given these answers, pedagogical reasons cannot by themselves justify their claim to teach critical thinking because those reasons only tell us what benefit (usefulness) critical thinking has. They indicate to us what critical thinking behaviors are likely to be (behaviorist approach). They do not yet tell us what critical thinking is.

Furthermore, those reasons may be given by any teacher in any given sub- ject without necessarily having to explicitly engage him/herself in critical thinking pedagogy. In other words, a Mathematics teacher may claim to teach Math in a way that his/her students are encouraged to think critically, creatively, to check axioms, to deduce correctly, etc. without claiming to teach critical thinking. What could justify so much discussion and literature about critical thinking if this cannot be distinguished with this teacher's pedagogy of teaching Math? If critical thinking is to be taken seriously, to provide a definition to the very concept of critical thinking becomes a necessity. This is not an exclusive concern of philosophers of education. "Such search for a definition is not merely a search for verbal equivalents -as in a dictionary- but rather a search for the conditions which must be satisfied" (Winch and Gingel, 1999: 56) before one can call a thinking behavior or pedagogy "critical."

The provision of an epistemologicallybased critical thinking concept is most importantly advantageous to the positing of critical thinking as a rational and educational ideal that is not necessarily bound to cultural traditions and historical situations. If critical thinking means Siegel's being appropriately moved by reason, it would less problematic to accept certain standards of reason assessment criteria regardless of cultural context. This would provide support to the justification of science and technology as courses that train in critical thinking. If critical thinking is unidentified with scientific thinking, and if it is understood that it is possible to be a critical thinker about science, one can critically think and infer that neither science nor criti- 
cal thinking is culture bound. Thus, Asians can be critical thinkers as they can be scientists just as much as Americans or Africans can. At least potentially, from the viewpoint of rationality, there are no discriminating apriori factors.

Lastly, in view of some educational implications this paper might lead to, it could be stated that a serious critical thinking agenda could begin with critical thinking in science understood in the strong sense. This means that while science can be given emphasis in the curriculum, critical thinking itself will critique that a curriculum limited to science and technology alone cannot be a serious critical thinking agenda. This is so because science cannot adequately critique itself. It cannot claim to be the model of rationality or the paradigm of critical thinking because its own merits and limits are inferred from a perspective that is not scientific. If and when science should claim to be paradigmatic of rationality and critical thinking, it would then have moved to the ambit and perspective of epistemology.

\section{References}

Alston, William. 1995. Concepts of Epistemic Justifications .In Human Knowledge. Classical and Contemporary Approaches, ed. by Paul Moser and Arnold vander Nat, pp. 321-340. NewYork: Oxford University Press.

Baoyun, Yang. 1998. The Relevance of Con fucianism Today. In Asian Values. An Encounter with Diversity, ed. by J. Cauquelin, P. Lim, and B. Mayer-König, pp.70-95. Surrey: Curzon Press.

Best, Edward. 1972. Common Confusions in Educational Theory. In Philo- sophical Analysis and Education, ed. by R.D. Archambault, pp. 3955. London: Routledge.

Cauquelin, J., Paul Lim and Birgit MayerKönig,. (eds). 1998. Asian Values. An Encounter with Diversity. Surrey. Curzon Press.

Cauquelin, J., Paul Lim and Birgit MayerKönig. 1998. Understanding Asian Values. In Asian Values. An Encounter with Diversity, ed. by J. Caquelin et al., pp. 1-19. Surrey: Curzon Press.

Hermida, Ranilo. 2000. Objectivity and Relativism - Illusion and Naiveté: The Hermeneutic Dimension of the Natural Sciences.

Kuhn, Thomas. 1970. The Structure of Sci entific Revolutions. $2^{\text {nd }}$ ed. Chicago: The University of Chicago Press.

Moser, Paul and Arnold vander Nat.. 1995. Human Knowledge. Classical and Contemporary Approaches. $2^{\text {nd }}$ ed. New York: Oxford University Press.

Pertierra, Raul. 1998. The Market in Asian Values. In Asian Values. An Encounter with Diversity, ed. by Caquelin et al., pp. 118-163. Sur rey: Curzon Press.

Pojman, Louis. 1995. What Can We Know? An Introduction to the Theory of Knowledge. California: Wadsworth Publishing Co.

Popper, Karl. 19971. La Logica de la investigacion científica. Madrid: Editorial Tecnos.

Reid, L. Arnaud. 1972. Philosophy and the Theory and Practice of Education. In Philosophical Analysis and Education, ed. by R.D. Archambault, pp. 17-37. London: Routledge

Siegel, Harvey. 1988. Educating Reason. Rationality, Critical Thinking and Education. New York \& London: Routledge.

Siegel, Harvey. 1997. Rationality Re deemed? Further Dialogues on an 
MANUSYA:Journal of Humanities(Special Issue. No.1-2.2001)

Educational Ideal. New York \& London: Routledge

Sklar, Lawrence. 2000. Theory and Truth. Philosophical Critique within Foundational Science. New York: Oxford University Press.

Tishman, Shari, David Perkins and Eileen Jay. 1995. The Thinking Class room. Learning and Teaching in a Culture of Thinking. Massachusetts: Allyn and Bacon.
Widjajakusumah, Muhammad, Djauhari Sri Widodo, Siti Oetarini, and Muhyidin Danakusuma. Problem Based Learning: A Method for Developing Critical and Productive Thinking - An Indonesian Experience. Paper presented at the $6^{\text {th }}$ Southeast Asian Ministers of Education Organization, 11-13 November, 1997. Manila

Winch, Christopher and John Gingell. 1999. Key Concepts in the Philosophy of Education. London \& New York. Routledge. 